\title{
Production of Disinfectant by Utilizing Eco-enzyme from Fruit Peels Waste
}

\author{
Rusdianasari $^{1}$, Adi Syakdani ${ }^{2}$, Muhammad Zaman ${ }^{2}$, Febby Fitria Sari ${ }^{2}$, \\ Nabila Putri Nasyta ${ }^{2}$, Rizka Amalia ${ }^{2}$ \\ ${ }^{1}$ Renewable Energy Engineering Department, Politeknik Negeri Sriwijaya, Palembang, Indonesia \\ ${ }^{2}$ Chemical Engineering Department, Politeknik Negeri Sriwijaya, Palembang, Indonesia
}

\section{Article Info}

Article history:

Received Oct 12, 2021

Revised Dec 10, 2021

Accepted Dec 25, 2021

\section{Keywords:}

Eco-Enzyme

Fermentation

Disinfectant

Fruit peels waste

\begin{abstract}
Organic waste is waste that contains carbon compounds that come from living things, such as fruit and vegetable waste. However, the community is still not able to manage it optimally, even though organic and non-organic waste can still be processed into useful products. This effective way can be realized through the manufacture of eco-enzymes that can be applied at the household level. Eco-enzyme is a liquid extract produced from the fermentation of vegetable and fruit residues with brown sugar as a substrate. The eco-enzyme has a strong sweet and sour fermented aroma due to the peels of oranges, pineapples, and papayas. This environmentally friendly enzyme can be produced using fruit peel, brown sugar, and water. Ecoenzyme solution when mixed with water, will react and can be used as a liquid disinfectant. Disinfectants commonly used are generally derived from synthetic chemicals in the form of artificial chemicals. One of the natural ingredients that can be used as a disinfectant is eco-enzyme liquid. This study aims to make a disinfectant using an environmentally friendly enzyme liquid, namely eco-enzyme. The method used in this research is a mixed method of fermentation of orange peel waste, pineapple and papaya, brown sugar, and water with a ratio of 3:1:10. Analysis for eco-enzyme $p H$, and Phytochemicals, while for disinfectants include $\mathrm{pH}$, total phenol content with $U V$-Vis Spectrophotometer, hard water emulsion stability, and antibacterial test. All samples of the disinfectant product met the requirements of SNI $06-$ 1842 of 1995, besides that, the best disinfectant product was found in a ratio of 1:10 which could reduce bacterial growth.
\end{abstract}

This is an open access article under the CC BY-SA license.

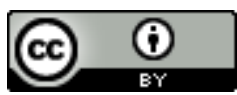

\section{Corresponding Author:}

Rusdianasari,

Renewable Energy Engineering Department, Politeknik Negeri Sriwijaya, Palembang, Indonesia

Jalan Srijaya Negara, Bukit Besar, Palembang 30139, Indonesia

Email: rusdianasari@polsri.ac.id

\section{INTRODUCTION}

Every day human activities are not spared from activities and produce a lot of waste or waste, be it organic or inorganic waste. In Indonesia, the amount of waste produced per day is on average $0.68 \mathrm{~kg}$ per person or 67.8 million tons of total national waste [1][2]. Inorganic waste is material that is considered useless and then discarded and cannot be decomposed again, examples of organic waste are vegetable waste, fruit residue, fruit peel and so on. The solution to the impact caused by fruit waste, fruit peel waste can be used as an alternative raw material to make eco-enzymes. 
Eco-Enzyme is a combination of organic waste. Eco-enzymes are complex liquids made by fermenting kitchen waste such as vegetables and fruit peels. Eco-enzymes are also included in homemade vinegar, reduced from alcohol by the fermentation process of kitchen waste as a substrate with sugar [3].

The idea of this eco-enzyme is to process enzymes from the waste or organic waste. Basically, ecoenzymes accelerate bio-chemical reactions in nature to produce useful enzymes using organic waste. This enzyme from organic waste is one way of waste management that utilizes kitchen scraps for something very useful [4][5]. Eco-enzymes act as antifungal, anti-bacterial and insecticidal agents. It can also be used as a cleaning agent or disinfectant.

This study aims to make a cleaning liquid or disinfectant from eco-enzyme, as a step in reducing the use of chemicals and replacing them with natural ingredients because Disinfectants commonly used are disinfectants whose raw materials are chemicals that aim to clean the area that transmits myco-organisms.

\section{RESEARCH METHODS}

\subsection{Tools and materials}

In this study the tools and materials used include: Hot plate, Analytical balance, Erlenmeyer, Beaker, Measuring beaker, Closed container, Knife, Filter, Filter paper, Watch glass, Measuring pipette, Test tube, Glass funnel, Dropper, pH paper, Volumetric flask, Rubber ball, Spatula, Stirring rod, Petri dish, Magnetic Stirrer, Oscillating wire, Wooden stirrer, Plastic bottle, Aluminum foil and Uv-Vis Spectrophotometer. In addition, the materials used in this study include pineapple peel, papaya peel, orange peel, brown sugar, water, $\mathrm{HCl}, \mathrm{NaOH}, 5 \% \mathrm{FeCl} 3$ solution, folin-ciocalteu reagent, gallic acid.

\subsection{Experimental procedure}

In the manufacture of eco-enzymes, the main thing that must be done is to clean the waste of orange peel, pineapple and papaya using clean water with the aim of being free from dirt that comes with the fruit skin. In addition, brown sugar is used as molasses and mixed with fruit peels that have been washed into a jar filled with water. The fruit rind and brown sugar that have been mixed are stirred until homogeneous. Then the eco-enzyme was fermented with variations of 2 months, 2.5 months and 3 months.

\subsection{Data Processing and Data Analysis Techniques}

In this research, the data is presented in tabular form according to the type of variable that describes the results of the eco-enzyme and disinfectant analysis. Data analysis carried out in this study is $\mathrm{pH}$ analysis by measuring the degree of acidity of the sample at room temperature with a $\mathrm{pH}$ meter or $\mathrm{pH}$ paper.

Organoleptic Test Testing using the five senses. Assessment with the senses, is widely used to assess the quality of agricultural products and food commodities [6].

Phytochemical Test Phytochemistry is a science that describes the chemical aspects of a plant [7] including flavonoid, saponin, quinone, tannin and phenolic tests. Flavonoids were evidenced by the presence of foam and the sample changed color to orange. Saponins can be detected by the foam test in water. Quinones are indicated by the formation of a yellow color. Tannins are evidenced by the formation of a blueblack or green-black color [8].

Phenol Qualitative Test showed the presence of green, red, purple, blue, or black strong blackish green and blackish blue [9].

Antibacterial Test Nutrient agar plates were spread with microbial suspension and samples were inoculated using the well diffusion method. These plates were incubated for 48 hours at $32 \mathrm{oC}$ and observed for the inhibition zone.

Determination of Total Phenol Content with Folin-Ciocalteu reagent was carried out by UV-Vis Spectrophotometer using Folin-Ciocalteau reagent and gallic acid as a standard for comparison.

Total Phenol Test Making a standard standard curve. The standard standard solution of gallic acid was added with Folin-Ciocalteu reagent and aquabides. The mixture was left for 10 minutes at room temperature, then $20 \%$ sodium carbonate was added. The mixture is then heated in a water bath at $40^{\circ} \mathrm{C}$. for 20 minutes and cooled rapidly in liquid ice. The results obtained were diluted with aquabides, then transferred into a cuvette, the absorption was read on a spectrophotometer at a wavelength of $760 \mathrm{~nm}$.

Determination of Total Phenol Test Testing total phenol test [10]. Eco-enzyme added folin-ciocalteu reagent and aquabides. The mixture was left for 10 minutes at room temperature, then $20 \%$ sodium carbonate was added. The mixture was heated in a water bath at $40^{\circ} \mathrm{C}$ for 20 minutes and immediately cooled in liquid 
ice, then diluted with aquabides and transferred to a cuvette, the absorption was read on a spectrophotometer at a wavelength of $760 \mathrm{~nm}[11][12]$.

Hard Water Emulsion Stability Measure the stability of the emulsion formed by mixing the sample with hard water. The stability of the water emulsion is indicated by the presence or absence of a layer separation and a precipitate from a floc [13][14].

The hedonic test is a test of consumer acceptance of the disinfectant product. The preference test used 25 panelists, where the panelists were asked to express their personal impressions about their likes or dislikes of an air freshener product with a preference scale. The scale used is 1 (not interesting), 2 (less attractive), 3 (quite interesting), 4 (interesting), 5 (very interesting) [15]-[17].

\section{RESULTS AND DISCUSSION}

\subsection{Eco-Enzyme Characteristic Test Results}

From the research that has been done, the product is a disinfectant from eco-enzyme. The variables used were the fermentation time of the eco-enzyme, namely 2 months, 2.5 months, 3 months and the ratio ratio of the disinfectants 1:10, 1:20, 1:30, 1:40, 1:50. The results of the eco-enzyme analysis can be seen in Table 1 .

Table 1. Characteristics of Eco-Enzyme

\begin{tabular}{cc}
\hline Characteristics of eco-enzymes & Results \\
\hline Color & Brown \\
Scent & Typical acid fermentation \\
$\mathrm{pH}$ & 4 \\
\hline
\end{tabular}

\subsection{Discussion}

Eco-enzymeis one of the results of the processing of organic waste that has many uses in everyday life. In the manufacture of eco-enzymes, the fermentation process is very important. The fermentation process lasts for 3 months. In the fermentation process carried out in a closed container or anaerobic fermentation, namely fermentation without the need for oxygen. In this fermentation process, brown sugar acts as a nutrient for microorganisms/bacteria so that the fermentation goes well. In the first month the eco-enzyme produces alcohol. In the second month eco-enzyme produces vinegar and in the third month produces enzymes. In the organoleptic test, the eco-enzyme has almost the same color. The resulting color depends on the brown sugar used. A good eco-enzyme $\mathrm{pH}$ is $<4$ or $=4$. The more acidic the $\mathrm{pH}$, the better the eco-enzyme produced.

Phytochemical test was carried out as a qualitative preliminary test to determine the chemical content of secondary metabolites in plants. These compounds determine the characteristics of the active compound causing the toxic effect or beneficial effect. Based on the results of the phytochemical test, it can be concluded that the eco-enzyme contains flavonoids, saponins, quinones, tannins and phenolics [18].

Fermentation in the eco-enzyme has a great influence on the phenol content.The level of phenol ecoenzyme in the initial conditions before fermentation was $184,552 \mathrm{mg} / \mathrm{L}$. After fermentation for 3 months, the phenol content of the eco-enzyme was $762,200 \mathrm{mg} / \mathrm{L}$. The total phenolic content of the eco-enzyme before and after fermentation had different values. The total phenolic content of the eco-enzyme after the fermentation process was higher than before the fermentation, thus indicating an increase in the total phenolic content.

In this study, eco-enzyme was used as a liquid disinfectant. Disinfectants are chemical preparations that can destroy or reduce the growth of microorganisms on the surface of inanimate objects such as instruments and surfaces. Disinfectants can not always kill all organisms, because there are types of microorganisms that are resistant. Disinfectants that are commonly used are disinfectants whose raw materials are chemicals that aim to clean areas that transmit mycoorganisms. Therefore, the use of chemicals needs to be reduced and replaced with natural ingredients. One of them is a disinfectant from eco-enzyme. The $\mathrm{pH}$ quality requirement of floor cleaning fluid according to SNI (Indonesian National Standard is 6-11, the disinfectant product tested shows results which meet the Indonesian National Standard. 


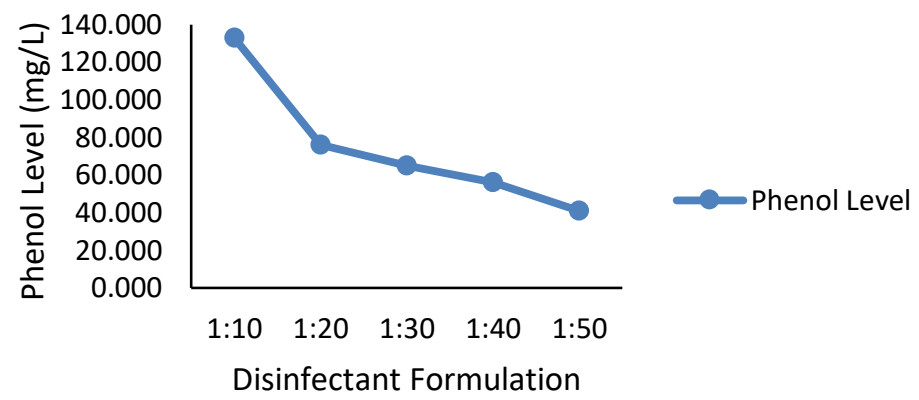

Figure 1. Phenol Level Graph

Based on Figure 1, it can be seen that the decrease in total phenol content was followed by a small comparison of the sample formula, so that the volume of eco-enzyme used as the volume of the dilution sample was small so that the phenol content also decreased. The total phenol content of each test sample had different results, because in the EC1 sample the ratio of 1:10 was the highest concentration, which was $132,940 \mathrm{mg} / \mathrm{L}$. Meanwhile, the EC5 sample with a ratio of 1:50 had the lowest total phenol content, which was $40,961 \mathrm{mg} / \mathrm{L}$. The increase in total phenolic content that occurs in the fermentation product can be caused by enzymatic reactions on the substrate, thereby releasing larger phenolic compounds as the final product.

In the emulsion stability test in hard water, it was found that after being left for 6 hours from 10 am to 4 pm. Hard water emulsion stability test of the formulated disinfectant preparations showed stable results, did not form a layer or precipitate (floc) in the mixture. This happens due to several factors, including the shape of the emulsion, the type of emulsifier used, the distribution of the solute between the two immiscible solvents and the surface tension.

The results of the antibacterial activity of the disinfectant liquid are intended to determine how well the disinfectant product inhibits the growth of bacteria from the floor of the Bioprocess Laboratory. The results of the antibacterial activity test showed that the less dilution, the less the number of colonies that grew. This proves that in the eco-enzyme content there are compounds that can effectively reduce bacterial growth. The phenolic compounds contained in the eco-enzyme are bactericidal. Phenol compounds will interact with the cell walls of microorganisms and cause protein denaturation, so that proteins undergo structural changes and will increase cell permeability so that cell growth will be inhibited and become damaged. In the results obtained, The most effective disinfectant in reducing the growth of bacterial colonies was a disinfectant with a ratio of 1:10. This is because based on observations, disinfectants with a ratio of $1: 10$ bacteria grow in small numbers.

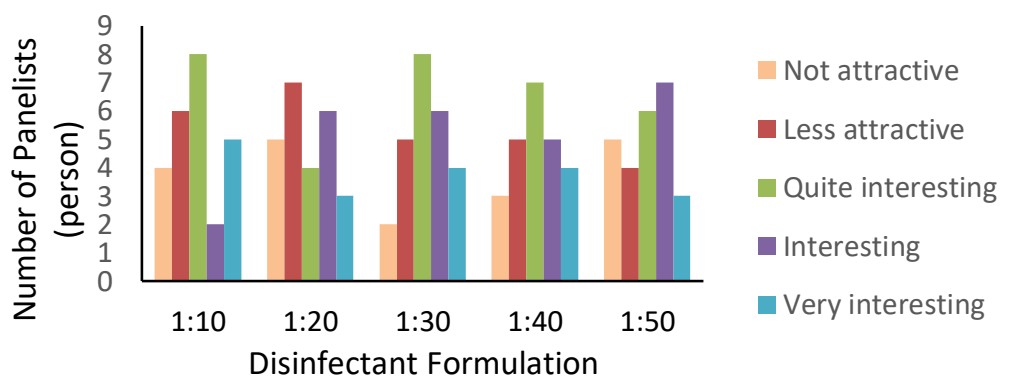

Figure 2. Graph of Preference for Disinfectant Colors

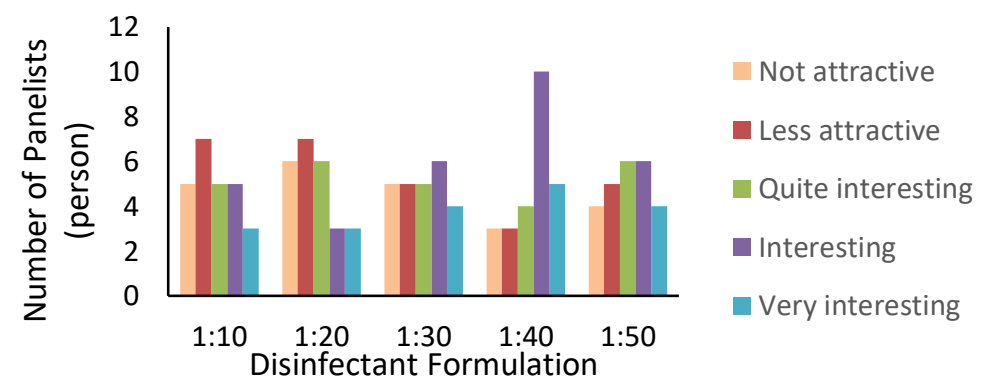

Figure 3. Graph of Preference for Disinfectant Smells 


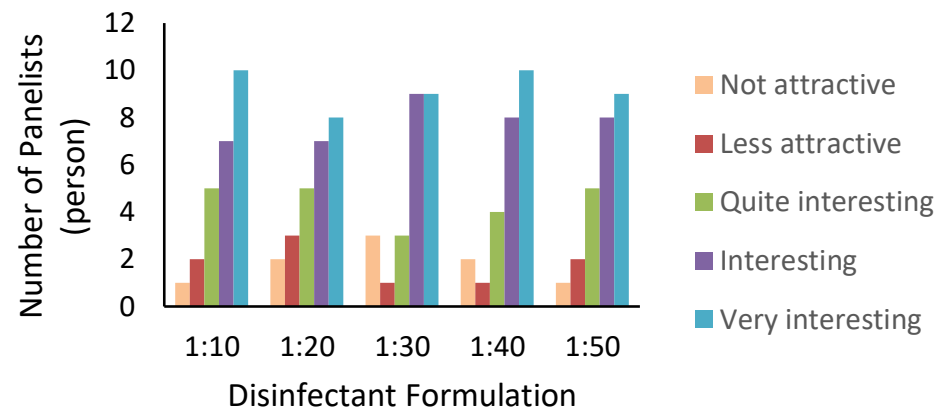

Figure 4. Graph of Preference for Disinfectants

From the three graphs above, it can be concluded that from all the existing formulas, the formula that is most accepted by the general public is 1:40, because it has a good shape, a not too pungent aroma and an attractive color.

\section{CONCLUSION}

Eco-enzyme is a versatile liquid fermented from fruit skin waste, brown sugar and water can be used as a disinfectant. Raw materials in the manufacture of eco-enzymes greatly affect the success rate in the fermentation process in eco-enzymes. The resulting eco-enzyme liquid is brown. The characteristic results of the eco-enzyme that have been fermented for 3 months have met the requirements as a good eco-enzyme, namely $\mathrm{pH}<4$ and a characteristic citrus aroma of fermentation. The use of chemicals in the manufacture of disinfectants needs to be reduced and replaced with natural ingredients. One of them is a disinfectant from eco-enzyme. The phenol content contained in the eco-enzyme liquid is effective in reducing bacterial growth so that it can be used as a disinfectant. At a sample dilution of 1:10 in the antibacterial test, it was seen that only a few bacteria or microorganisms grew.

The results of the quality characteristics of the disinfectant, namely $\mathrm{pH}$, and the stability of the hard water emulsion for each sample have met the requirements based on SNI $06-1842$ of 1995, namely pH 6 11 and stable emulsion stability in hard water. In the sample dilutions of 1:10, 1:20, 1:30, 1:40 and 1:50 the $\mathrm{pH}$ values obtained are 6-7 where these values meet the quality requirements of disinfectant. In the hard water stability test, all samples of the disinfectant product have stable emulsion stability in hard water, because there is no formation or no sediment or coating on the sample of the disinfectant product and it meets the quality requirements of the disinfectant.

\section{REFERENCES}

[1] Rusdianasari, A Taqwa, A Syakdani, Jaksen, Treatment of Landfill Leachate by Electrocoagulation using Aluminum Electrode, Matec Web of Conference 101 (EDP Science), 02010, 2017.

[2] A. Meidinariasty, Rusdianasari, Y. Bow, I. Rusnadi, A.L. Fuadi, Treatment of leachate from garbage using electrocoagulation type MP-P (Monopolar-Paralel) Methode, IOP Conf. Series: Journal of Physic 1167(012054), doi:10.1088/1742-6596/1167/1/012054. 2019.

[3] Rusdianasari, A Syakdani, Y Bow, T Dewi, AJ Shodiq, S Arita, Combination of Electrocoagulation and Aeration Processes by Addition $\mathrm{NaCl}$ for Leachate Treatment, International Journal on Advanced Sciences Engineering Information Technology, Vol. 10(6), 2020.

[4] Xia, Li, hang Wang Eco-stoichiometric alteration in Paddy Ecosystem, 2013.

[5] Modul Belajar Pembuatan Eco-Enzyme 2020. Eco Enzyme Nusantara Bersama Kita Bisa.

[6] Vama, Laspia., 2020. Production, Extraction and Uses Of Eco-Enzyme Usingcitrus Fruit Waste: Wealth From Waste. Asian Jr. of Microbiol. Biotech. Env. Sc. Vol. 22 No. 2.

[7] Purba, R.D 2001. Analisis Komposisi Alkaloid Daun Handeuleum (Graptophyllum pictum (Linn), Griff) yang Dibudidayakan dengan Taraf Nitrogen yang Berbeda. (Skripsi). Bogor: Institut Pertanian Bogor.

[8] Chandra, Yulie Neila., Hartati, Dewi., Wijayanti, Gustini., Gunawan, Hin Goan., 2020. Sosialisasi Pemanfaatan Limbah Organik Menjadi Bahan Pembersihan Rumah Tangga.Prosiding Seminar Nasional Pengadian kepada Masyarakat: Jakarta.

[9] Soekarto ST.1981.Penilaian Organoleptik.Bogor:Pusbangtepa,Institut Pertanian Bogor.

[10] Harborne, J.B.1987. Metode Fitokimia.Edisi ke-2.ITB.Bandung.

[11] Supomo, Supriningrum R. dan Junaidi, R.2016. Karakterisasi Dan Skrining Fitokimia Daun Kerehau. Farmakognasi Akfar. Vol 13 No 2 hal 89-96. 
[12] Suerni, Endang., 2013. Uji Daya Hambat Ekstrak Buah Nanas (Ananas comosus L. Merr.), Salak (Salacca edulis Reinw.) dan Mangga Kweni (Mangifera odorata Griff.) terhadap Daya Hambat Staphylococcus Aureus. Universitas Tadulako Kampus Bumi Tadulako Tondo Palu. Sulawesi Tengah.

[13] Purwantiningsih, Theresia Ika., Suranindyah, Yustina Yuni, Widodo.2014.Aktivitas Senyawa Fenol Dalam Buah Mengkudu Sebagai Antibakteri Alami Untuk Penghambatan Bakteri Penyebab Mastitis. Yogyakarta:Buletin Perternakan.

[14] SNI [Standar Nasional Indonesia]. 1995. Standar Mutu Pembersih Lantai No. 06 - 1842-1995. Jakarta. Badan Standar Nasional.

[15] SNI [Standar Nasional Indonesia]. 2006. Standar Mutu Pembersih Lantai No. 01-2346-2006. Jakarta. Badan Standar Nasional.

[16] Waluyo, L., 2010. Teknik dan Metode Mikrobiologi. Malang Cetakan kedua. UMM Press. Halaman 110.

[17] Zetra Y, Prasetya P., 2007. Isolasi senyawa $\alpha$-amirin dari tumbuhan Beilschmiedia roxburghiana (Medang) dan uji bioaktivitasnya. Akta Kimindo, 3: 27-30.

[18] Rusdianasari, A. Syakdani, M. Zaman, F.F. Sari, N. P. Nasyta, R. Amalia, Utilization of Eco-Enxymes from Skin Waste as Hand Sanitizer. Asian Journal of Applied Research for Community Development and Empowerment (AJARCDE), Vol. 5(3), 2021.

\section{BIOGRAPHIES OF AUTHORS}
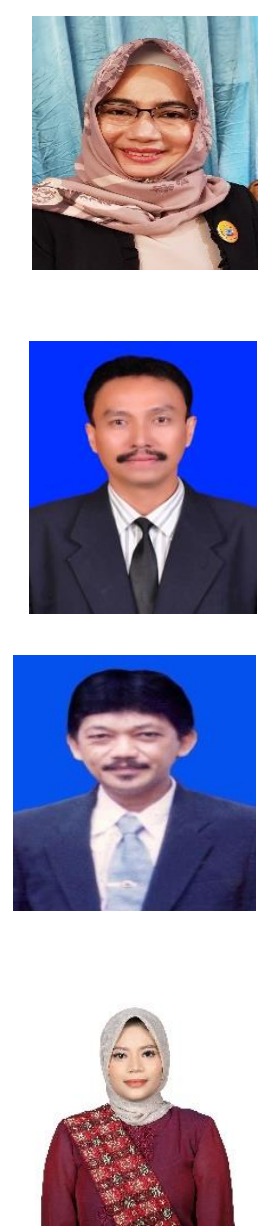

Prof. Dr. Ir. Rusdianasari, M.Si., IPM., was born in Palembang on 19th November 1967. She earned a bachelor's degree in Chemical Engineering from Universitas Sriwijaya in 1991. She continued pursuing postgraduate in 1999 and graduated in 2001 with a Master Degree in Chemistry from Institut Teknologi Bandung (ITB). She graduated with Doctoral Degree in Environmental Science 2014 from Universitas Sriwijaya, Palembang, Indonesia. The study programs taught include D3 Chemical Engineering since 1991, D4 Energy Engineering since 2014, D4 Industrial Chemical Technology started in 2015, and Renewable Energy Masters since 2016.

Adi Syakdani, S.T., M.T., was born in Palembang, April 11, 1969. He earned a bachelor's degree in Chemical Engineering from Universitas Sriwijaya in 1996. He continued pursuing postgraduate in 2009 and graduated in 2012 with a Master Degree in Chemical Engineering from Universitas Sriwijaya.

Ir. M. Zaman, M.Si., M.T., was born in OKI-Sidakersa on 3th July 1959. He earned a bachelor's degree in Chemical Engineering from Universitas Sriwijaya in 1988. He continued pursuing postgraduate in 2007 and graduated in 2009 with a Master Science in Public Administration from Universitas Sjakhyakirti Palembang. He graduated with a Master Degree in Environmental Science 2012 from Universitas Sriwijaya, Palembang, Indonesia. The study programs taught include D3 Chemical Engineering since 1989, D4 Energy Engineering since 2014, D4 Industrial Chemical Technology started in 2021.

My name is Nabila Putri Nasyta. I was born in Palembang, November 9th 2000. I am an active student in Sriwijaya State Polytechnic majoring in Chemical Engineering 2018 Diploma III. I live at Villa Angkasa Permai Blok A No 1 Palembang, South Sumatra. I like baking cakes and growing ornamental plants to spend my free time. 


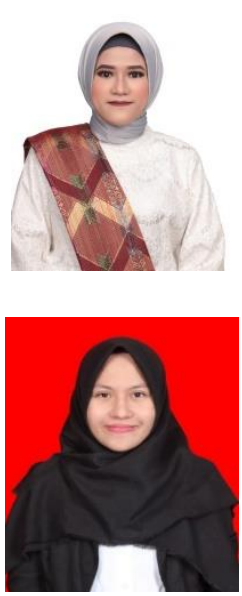

Febby Fitria Sari, born in Prabumulih, December 28th 2000, is an active student in Polytechnic majoring Chemical Engineering 2018 Diploma III. Address Captain Abdullah RT.12 RW.05, Prabumulih, South Sumatra.

Rizka Amalia, born in Palembang, April 21th 2001, is an active student in Polytechnic majoring Chemical Engineering 2018 Diploma III. AddressGriya Mitra II Block H02 RT.43 RW.13, Palembang, South Sumatra. 